\title{
THE CANADIAN ENVIRONMENTAL ASSESSMENT ACT and Global Climate Change: Rethinking Significance
}

\author{
TOBY KRUGER*
}

Environmental assessments conducted under the Canadian Environmental Assessment Act turn on the key finding of whether a proposed project is likely to cause significant adverse environmental effects. Despite the importance of "signifcance" in the assessment process, the lack of objective criteria to determine when the threshold of significant has been reached in the greenhouse gas emissions context has made the process ineffective. This prevents meaningful judicial review and the regulatory scheme from properly confronting climate change. The article examines how significance might be objectified under the current regulatory and government policy framework, including the possibility of establishing benchmarks, assessing relative significance by comparing the proposal to alternatives, and the use of mitigation strategies.
Les études d'impact, menées en vertu de la Loi canadienne sur l'évaluation environnementale, reposent sur la conclusion clé qui consiste à déterminer dans quelle mesure un projet aura des conséquences négatives importantes pour l'environnement. Malgré la portée du mot «important » dans l'étude d'impact, le processus est inefficace en raison du manque de critères objectifs permettant de déterminer à quel moment le seuil des conséquences négatives est atteint dans le contexte des émissions de gaz à effet de serre. On évite ainsi une révision judiciaire concrète et le système de réglementation ne peut faire face au changement climatique comme il se doit. L'article examine de quelle manière on peut objectiver la mesure de l'importance compte tenu du cadre réglementaire et stratégique actuel, incluant la possibilité d'établir des repères, d'évaluer une importance relative en comparant le projet aux solutions de rechange, et le recours à des stratégies de modération.

\section{TABLE OF CONTENTS}

I. INTRODUCTION . . . . . . . . . . . . . . . . . . . . . . . . . . . . . . . 162

II. SetTing The StAGE . . . . . . . . . . . . . . . . . . . . . . . . . . . . . 164

A. The Proposed Kearl Project $\ldots \ldots \ldots \ldots \ldots \ldots \ldots \ldots$

B. The KeArl EnVIRONMENTAL AsSESSMENT . . . . . . . . . . . 165

C. The ResPonsible Authority's Decision . . . . . . . . . . . 167

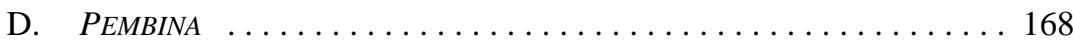

III. SIGNIFICANCE . . . . . . . . . . . . . . . . . . . . . . . . . . . 169

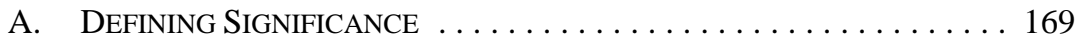

B. Articulating SignificANCE IN THE GHG CONTEXT . . . . . . . . 171

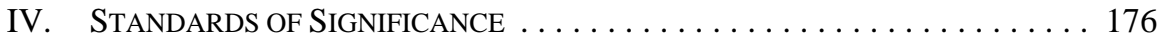

A. The Regulatory Approach: Identifiable Thresholds . . . . 176

B. The Judicial ApProach: AnAlysis of Alternatives . . . . . . 177

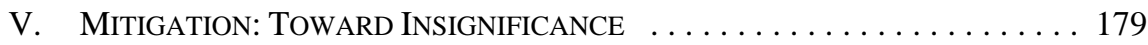

A. DegreE of Mitigation $\ldots \ldots \ldots \ldots \ldots \ldots \ldots \ldots \ldots \ldots$

B. Emissions TRAding: Method of Mitigation? . . . . . . . . . 181

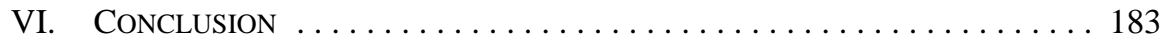

LL.B. (with distinction) 2009, University of New Brunswick (UNB). This article was the recipient of the Barry Morrison Prize in Legal Writing at UNB in 2009. The author would like to thank Professor Neil Craik for his helpful comments on earlier drafts of this article. 


\section{INTRODUCTION}

The recent environmental assessment (EA) conducted for Imperial Oil's Kearl oil sands project came to the conclusion that the proposed project, forecast to release 0.5 percent of Canada's annual greenhouse gas (GHG) emissions, was not likely to cause significant adverse environmental effects. ${ }^{1}$ Several groups opposed this finding and applied for judicial review. In Pembina, ${ }^{2}$ the Federal Court allowed the judicial review application in part, holding that the EA failed to explain how the amount of GHG emissions from the proposed project could be insignificant, thus leaving the requisite elements of the Canadian Environmental Assessment Act ${ }^{3}$ unsatisfied. The Court directed that the EA be supplemented with a rationale for the conclusion that the project's GHG emissions were not likely to cause significant adverse environmental effects. ${ }^{4}$ Despite a successful challenge to the decision, the case is an example of how litigants have tried — but ultimately failed — to use the CEAA to confront climate change in Canada. While recognizing that the project's forecasted GHG emissions were considerable, the supplemental rationale stated that "there was very little evidence ... to suggest that this release will result in significant adverse environmental effect." 5 To the contrary, it reasoned that Imperial Oil's adherence to the Alberta government's GHG intensity targets will likely mitigate any significant environmental effects from the project. ${ }^{6}$ Thus, the EA's final conclusion remained unchanged: the project was not likely to cause significant adverse effects. This rationale was accepted by the Canadian government, and three months after Pembina, the Kearl project was approved. ${ }^{7}$

Pembina is important because it is the first time a Canadian court has held that unmitigated GHG emissions from a proposed project could be significant. ${ }^{8}$ Put simply,

Imperial Oil Resources Ventures Limited: Application for an Oil Sands Mine and Bitumen Processing Facility (Kearl Oil Sands Project) in the Fort McMurray Area (27 February 2007), EUB Decision 2007013 at 1, online: Energy Resources Conservation Board (ERCB) <http://www.ercb.ca/docs/ documents/decisions/2007/2007-013.pdf> [Panel Report].

2 Pembina Institute for Appropriate Development v. Canada (Attorney-General), 2008 FC 302, 323 F.T.R. 297 at para. 79 [Pembina].

$3 \quad$ S.C. 1992, c. 37 [CEAA].

$4 \quad$ Pembina, supra note 2 at paras. 73, 80.

$5 \quad$ Kearl Oil Sands Project: Additional rationale for the Joint Review Panel's Conclusion on Air Emissions (6 May 2008), Addendum to EUB Decision 2007-013 at 6, online: ERCB <http://www.ercb. ca/docs/documents/decisions/2007/2007-013-Addendum.pdf > [Panel's Additional Rationale]. Except where otherwise indicated, all references to the Kearl Panel's EA in this article refer to the original Panel Report, supra note 1, that was challenged on judicial review. The Panel's additional rationale has not been challenged.

$6 \quad$ Panel's Additional Rationale, ibid.; Alberta's emissions intensity targets are enabled by the Climate Change and Emissions Management Act, S.A. 2003, c. C-16.7, s. 3, and found in the Specified Gas Emitters Regulation, Alta. Reg. 139/2007. They are based on the assumption that emissions targets relative to gross domestic product (GDP) are currently sufficient measures to combat climate change. Kearl Oil Sands Project - Mine Development (5 June 2008), Decision, online: Canadian Environmental Assessment Agency (CEAA) <http://www.ceaa.gc.ca/050/details-eng.cfm?CEAR_ID= 16237\&ForceDecision=Y\&DecisionID=20218 > [Government of Canada's Kearl Decision]. See also CEAA, "The Government of Canada's Response to the Environmental Assessment Report of the Joint Review Panel on the Kearl Oil Sands Project," online: CEAA <http://www.ceaa.gc.ca/050/Documenteng.cfm?DocumentID=22841>[Government of Canada's Kearl Response].

$8 \quad$ GHG emissions have been considered in other EA reviews but judicial review challenges on the basis of GHG emissions have either not been made or not been successful: see e.g. Prairie Acid Rain Coalition v. Canada (Minister of Fisheries and Oceans), 2004 FC 1265, 257 F.T.R. 212, aff'd 2006 
significance is the linchpin for a final project decision in EA. Generally, if an EA determines that a project is likely to have significant adverse environmental effects, absent appropriate mitigation measures or overriding policy justifications, the project will not be allowed to proceed. GHGs, however, pose special problems for the definition of significance. Relative to worldwide emissions, an individual project's GHG emissions are singly indeterminate of global climate change impacts, while cumulative effects from GHG emissions worldwide are immense. Is one project's minor contribution to a massive problem therefore insignificant? Or does the size of the problem itself require that all projects contributing to climate change be labelled as significant? Given the wide scientific consensus linking GHG emissions to climate change, ${ }^{9}$ the importance of climate change concerns on political ${ }^{10}$ and public agendas, ${ }^{11}$ and directives by the Canadian Environmental Assessment Agency to incorporate climate change considerations into EA, ${ }^{12}$ identifying the environmental effects of a project's GHG emissions is likely to be a salient issue in future EAs.

As was the case in Pembina, the primary challenge for future EAs will be to give meaning to the term "significant" in the context of GHG emissions. This article explores that challenge and suggests how one project's potentially significant GHG emissions can be articulated in future EA decisions while respecting both the letter and the spirit of the CEAA. Part II of this article provides a background for the analysis by explaining the nature of the GHG problem as well as outlining the CEAA process through a review of the events culminating in Pembina. Part III begins by addressing the meaning of significance in the abstract, and then discusses significance as it relates to GHG emissions specifically, particularly with reference to cumulative effects. Part IV examines how the significance of GHG emissions might be objectified through the regulatory and judicial contexts. Part V addresses how mitigation measures can reduce a project’s significant environmental effects

FCA 31, [2006] 3 F.C.R. 610; Express Pipeline Project (10 May 1996), Report of the Joint Review Panel, online: National Energy Board (NEB) <www.neb-one.gc.ca>; Georgia Strait Crossing Pipeline Limited on behalf of GSX Canada Limited Partnership (November 2003), Reasons for Decision GH-42001 (NEB), online: NEB <http://www.neb.one.gc.ca> [GSX Report]; Emera Brunswick Pipeline Company Ltd. (May 2007), Reasons for Decision GH-1-2006 (NEB), online: NEB <http://www.nebone.gc.ca>.

9 The Intergovernmental Panel on Climate Change (IPCC) has concluded that "[m]ost of the observed increase in global average temperatures since the mid-20th century is very likely due to the observed increase in anthropogenic GHG concentrations.” This conclusion was reached on the basis that it is "extremely unlikely that global climate change of the past 50 years can be explained without external forcing and very likely that it is not due to known natural causes alone”: see Core Writing Team, Rajendra K. Pachauri \& Andy Reisinger, eds., Climate Change 2007: Synthesis Report (Geneva: Intergovernmental Panel on Climate Change, 2008) at 39, online: IPCC <http://www.ipcc.ch/pdf/ assessment-report/ar4/syr/ar4_syr.pdf> [IPCC Report] [emphasis in original].

10 Shawn McCarthy \& Campbell Clark, “Ottawa Swoops in with Climate Change Offer” The Globe and Mail (6 November 2008) A1.

11 HSBC Climate Partnership, Climate Confidence Monitor 2008 (London: HSBC, 2008) at 2, online: HSBC <http://www.hsbc.com/1/PA_1_1_S5/content/assets/csr/climate_confidence_monitor_2008. pdf $>$ ("Forty three per cent of those surveyed chose climate change ahead of global economic stability when asked about their top three concerns, despite the survey taking place in the midst of the financial market turmoil in September-October 2008”).

12 The Federal-Provincial-Territorial Committee on Climate Change and Environmental Assessment, Incorporating Climate Change Considerations in Environmental Assessment: General Guidance for Practitioners (Ottawa: The Federal-Provincial-Territorial Committee on Climate Change and Environmental Assessment, 2003). 
and asks whether the federal government's Turning the Corner ${ }^{13}$ plan contains GHG emissions reduction strategies that might constitute appropriate mitigation measures under the $C E A A$. The article concludes that, by drawing upon existing tools familiar to EA practice, it is possible to articulate acceptable GHG emissions thresholds that identify significance within the CEAA framework. This article further concludes that accounting for a project's GHG emissions need not paralyze project approvals; where emissions thresholds are exceeded, verifiable mitigation measures that decrease GHG emissions can temper a finding of significance and permit projects to proceed.

\section{SETTING THE STAGE}

\section{A. The Proposed KeArL Project}

As part of its plan to develop Alberta's oil sands, Imperial Oil proposes to construct the Kearl oil sands project. ${ }^{14}$ The project includes the construction and operation of four open pit mines, bitumen extraction facilities, tailings management facilities, and other supporting infrastructure, with a view to producing up to 345,000 barrels of oil per day. ${ }^{15}$ Apart from its physical size, what is most remarkable about the project is its projected GHG emissions, in the order of 3.7 million tonnes of carbon dioxide equivalent $\left(\mathrm{CO}_{2} \mathrm{e}\right)$ per year. ${ }^{16}$ According to Imperial Oil, this is equivalent to the GHG emissions of 800,000 passenger vehicles every year, and represents 0.51 percent and 1.7 percent respectively of Canada and Alberta's annual GHG emissions. ${ }^{17}$ Additionally, the project involves the alteration, disruption, or destruction of fish habitat, which requires an authorization from the federal Minister of Fisheries and Oceans (DFO) pursuant to s. 35(2) of the Fisheries Act, an event that triggered the federal EA process. ${ }^{18}$

A primary purpose of the CEAA is to ensure that projects carried out in Canada do not cause significant adverse environmental effects. ${ }^{19}$ This is achieved through a two-step process: first through an EA of the project, and second through the making of a project decision on the basis of that EA. The EA is to "provide the decision maker with an objective basis for granting or denying approval for a proposed development,” and, as described below,

Environment Canada, Turning the Corner: Regulatory Framework for Industrial Greenhouse Gas Emissions (Ottawa: Environment Canada, 2008), online: Environment Canada <http://www.ec.gc.ca/ doc/virage-corner/2008-03/pdf/COM-541-Framework.pdf> [Turning the Corner].

See “Kearl Oil Sands: Overview,” online: Imperial Oil <http://www.imperialoil.ca/Canada-English/This Is/Operations/TI_O_Kearl_Overview.asp>.

Ibid.

GHGs differ in their influence on climate change because of their lifetimes in the atmosphere and radiative properties. "Carbon dioxide equivalent" is a conversion that is made to compare the mass of carbon dioxide that would produce the same global warming impact as a given mass of another GHG. See IPCC report, supra note 9 at 36 and Pembina, supra note 2 at para. 70.

Pembina, ibid. (based on 2002 emissions).

Fisheries Act, R.S.C. 1985, c. F-14, s. 35(2). Federal participation in a project, either as landowner, proponent, funder, or regulator, triggers the requirement for an EA: see CEAA, supra note 3 , s. 5. CEAA, ibid., s. 4(1)(a). 
qualifies the decision-maker's discretion when deciding whether to permit the project to be carried out. $^{20}$

\section{B. THE KEARL ENVIRONMENTAL ASSESSMENT}

All projects requiring an EA must produce either a screening or a comprehensive study report. This report will yield one of three conclusions. ${ }^{21}$ If a project is not likely to cause significant adverse environmental effects, the federal responsible authority (RA) may allow the project to proceed. ${ }^{22}$ If a project will cause significant adverse environmental effects that cannot be justified in the circumstances, the RA is precluded from allowing the project to proceed. ${ }^{23}$ If, however, the report is inconclusive on the significance of the effects, or if the effects are potentially justifiable, or if public concern warrants it, the project will be referred to a review panel or mediator for a more reaching assessment. ${ }^{24}$ Because of the Kearl project's potential to cause significant adverse environmental effects, the DFO recommended that the project be referred to a review panel. ${ }^{25}$

DFO's initial decision that the Kearl project had the potential to cause significant adverse environmental effects is not to be confused with the final determination of whether the project was likely to cause significant adverse environmental effects. What differentiates these steps in an EA is the extent to which a project's predicted impacts are scrutinized. At the screening stage or in a comprehensive review, project decisions are based upon a selfdirected review conducted by the RA for the project. ${ }^{26}$ In a panel review, project decisions are based upon an independent expert review of the project's environmental effects. ${ }^{27}$ Significance does not necessarily have a different meaning at these different levels of EA

Friends of the Oldman River Society v. Canada (Minister of Transport), [1992] 1 S.C.R. 3 at 71 [Oldman River]. Although this case was decided under the predecessor to the CEAA, the Environmental Assessment and Review Process Guidelines Order, S.O.R./84-467 [EARPGO], much of the jurisprudence under EARPGO is still relevant. Oldman River, for example, was cited in Pembina, supra note 2 at para. 15.

For screenings, this decision is taken pursuant to the CEAA, supra note 3, s. 20. For comprehensive reviews and panel reviews, this decision is taken pursuant to s. 37.

For screening reports, see CEAA, ibid., s. 20(1)(a). The federal authority that proposes to participate in the project becomes the RA. The RA is legally responsible for ensuring the EA is carried out. For example, because the Kearl project required an authorization under s. 35(2) of the Fisheries Act, the DFO became the RA: see supra note 18 and accompanying text.

CEAA, ibid., s. 20(1)(b).

Ibid., s. 20(1)(c).

Pembina, supra note 2 at para. 8. The CEAA, ibid., s. 28 allows the Minister of Environment to refer the project's EA to a review panel.

Some projects, like Kearl, are deemed by regulation to have the potential for such a significant impact that they are initially required to undergo a comprehensive study instead of a screening. Oil sands developments, for example, are by their very nature deemed to be so significant that all proposed developments reaching a minimum size threshold are subject to comprehensive review. The regulations focus more upon the type of project proposed, rather than the actual project proposed: see Comprehensive Study List Regulations, S.O.R./94-638, s. 11(c).

Independent reviews are conducted by a panel of experts with no affiliation to the RA. "Joint" panel reviews are often ad hoc bodies appointed by provincial and federal authorities to satisfy both federal and provincial EA requirements: see e.g. the Canada-Alberta Agreement on Environmental Assessment Cooperation (2005), online: CEAA <http://www.ceaa.gc.ca/010/0001/0003/0001/0001/2005 agreement_e.htm>. Expert review panels are required to hold hearings open to the public and are to arrive at a technically and scientifically driven determination of a project's environmental effects. 
review, but sometimes a final project decision can be made without higher levels of project scrutiny. ${ }^{28}$ In this case, while it was known early in the comprehensive review that oil sands projects have the potential to cause serious adverse environmental effects, the extent of the Kearl project's specific impacts were not known. ${ }^{29}$ Therefore, to come to a final conclusion on significance, it was necessary to conduct a more stringent panel review of the project itself.

The $C E A A$ contains several procedural obligations a review panel must adhere to. Like all review panels, the Kearl Panel was required to set out the "rationale, conclusions and recommendations of the panel relating to the environmental assessment of the project." ${ }^{{ }^{30}}$ The results of the EA were to be summarized in a report and submitted to the DFO. To this end, the CEAA procedure mandated that the report contain a discussion of specific factors, including a summary of public comments, mitigation measures, the project's purpose, alternative means of carrying out the project, the need for a follow-up program, and the capacity of renewable resources likely to be affected by the project. ${ }^{31}$ Importantly, the report was required to contain a discussion of the significance of the project's environmental effects, including any cumulative effects likely to result from the project. ${ }^{32}$ The Panel was to "have knowledge or experience relevant to the anticipated environmental effects of the project," and was to obtain all necessary information required for the assessment. ${ }^{33}$ In short, the Panel's role was to conduct a "science and fact-based assessment" of the project's potentially adverse environmental effects. ${ }^{34}$ It was required to explain whether the "potential environmental effects, either with or without the implementation of mitigation measures, [would] be significant." ${ }^{35}$ Critically, the Panel had a requirement to articulate a robust understanding of scientific reports and any evidence presented to it.

Taking into account the evidence on project effects and mitigation measures before it, the Panel wrote: "The Joint Panel concludes that the [Kearl Oil Sands] Project is not likely to cause significant adverse environmental effects, provided that the proposed mitigation measures and the recommendations of the Joint Panel are implemented. ${ }^{36}$

Scening is necessary to ensure efficiency in the EA process. Screening ensures that potentially insignificant projects are not unnecessarily addressed, while simultaneously ensuring that potentially significant projects are properly addressed. Interestingly, there is no indication that the potential for GHG emissions specifically prompted the panel review in this case.

CEAA, supra note 3, s. 34(c)(i).

These are mandatory considerations for all panel reviews and are found in ibid., ss. 16(1)-(2).

Ibid., ss. 16(1)(a)-(b).

Ibid., ss. 33(1)(a)(i), 34(a).

Pembina, supra note 2 at para. 72.

Ibid. at para. 73.

Panel Report, supra note 1 at 1. 


\section{THE RESPONSIBLE AUTHORITY's Decision}

Upon receiving the Panel's report, the DFO was required to make a final project decision based on the evidence and conclusions in the report. At the heart of the DFO's statutory duties lay s. 37(1), the CEAA's "fundamental decision-making provision": ${ }^{37}$

(a) where, taking into account the implementation of any mitigation measures that the responsible authority considers appropriate,

(i) the project is not likely to cause significant adverse environmental effects, or

(ii) the project is likely to cause significant adverse environmental effects that can be justified in the circumstances,

the responsible authority may exercise any power or perform any duty or function that would permit the project to be carried out in whole or in part; or

(b) where, taking into account the implementation of any mitigation measures that the responsible authority considers appropriate, the project is likely to cause significant adverse environmental effects that cannot be justified in the circumstances, the responsible authority shall not exercise any power or perform any duty or function conferred on it by or under any Act of Parliament that would permit the project to be carried out in whole or in part. ${ }^{38}$

While the Panel conducted the EA, the final project decision was for the RA to make, with approval from Cabinet, including the Minister of Environment. ${ }^{39}$ The significance of the project's adverse environmental effects was central to this final decision. Since the Panel concluded that the project's impacts were not likely to be significant, pursuant to s. 37(1)(a)(i), an authorization was issued to allow the Kearl project to be carried out. ${ }^{40}$ It was perhaps open to the RA to come to a different conclusion on significance than the Panel, but this is unlikely given the RA's legal requirement to take the Panel's report into consideration. If the Panel's report was based on the best evidence available, it would have been difficult for the RA to contradict the Panel's conclusions. ${ }^{41}$

Beverly Hobby et al., Canadian Environmental Assessment Act: An Annotated Guide, looseleaf (Aurora: Canada Law Book, 2008) at II-132.

CEAA, supra note 3, s. 37(1).

See ibid., s. 37(1.1).

See Government of Canada's Kearl Decision, supra note 7. The original project authorization referred to here is no longer available on the Canadian Environmental Assessment Registry, but it is assumed that the original 12 February 2008 authorization is identical in substance to the 5 June 2008 authorization issued after the Panel's supplemental reasons were released.

While the CEAA does not formally prevent the RA from drawing different conclusions than the review panel, the RA must explain its reasons in a public notice of decision, and as a result is subject to considerable public scrutiny: see e.g. Government of Canada's Kearl Response, supra note 7. An example of a case where the RA did not accept the review panel's recommendation occurred with respect to the Oldman River dam (subject of the Oldman River case, supra note 20), where the Panel recommended that a hydroelectric dam be decommissioned to allow unimpeded river flow: see Federal Environmental Assessment Review Office, Oldman River Dam: Report of the Environmental Assessment Panel (Hull: Federal Environmental Assessment Review Office, 1992). Nevertheless, the RA permitted the project to proceed. However, this case may be unusual because the panel's 
What is more likely is that had the Panel concluded that the project was likely to cause significant adverse environmental effects, the RA would need to consider whether those effects could be justified in the circumstances. Section 37(1)(a)(ii) of the CEAA requires that, where a project has reached the threshold of significant adverse environmental impact, that threshold should not be exceeded without justification. However, the CEAA provides no guidance on how significant adverse environmental effects are to be justified. ${ }^{42}$ Short of an arbitrary decision that falls outside of the CEAA's policy objectives, the justification decision (again, taken by the RA with Cabinet approval) would be difficult to challenge on judicial review.

While the CEAA does not provide guidance on how a project can be justified, it provides extensive guidance to panels on the contents of the reports they must submit. A panel's report is the "essential statutory prerequisite" for decision-making under s. 37, and the report's adequacy can be challenged without challenging the RA's decision itself. ${ }^{43}$ If there is a deficiency in the report, such as in Pembina, the RA is no longer entitled to rely on it. This was highlighted in a proceeding related to Pembina, where it was determined that since the Joint Panel's original EA report was "fundamentally flawed," the RA could not rely on it to give project authorization. ${ }^{44}$ The panel's requirement to publish reasons at once makes the statutory decision-maker accountable to the public and makes the panel's decisions vulnerable to judicial review. Where an RA acts on the panel's conclusion that a project's forecasted impacts are insignificant, it is the panel, and not the RA, that must ensure the defensibility of the report's conclusions. ${ }^{45}$ Whether or not a panel's substantive conclusions on significance will be upheld depends on its adherence to procedure in the statutory scheme.

\section{PEMBINA}

Alleging that the Panel did not comply with the mandatory steps in the CEAA, a coalition of non-profit organizations brought an application for judicial review. Amongst other issues, the applicants alleged that the Panel failed to provide a rationale for its conclusion that GHG emissions would be insignificant. It was not the Panel's rationale that was attacked. Rather, it was the alleged failure to provide any rationale at all.

recommendation arose as a result of a retrospective court order to conduct an EA. The litigation over whether an EA should be conducted was not resolved until well after construction on the dam had already begun: see generally Christopher Wood, Environmental Impact Assessment: A Comparative Review, 2d ed. (Harlow: Pearson Education, 2003) at 232-33.

42 Hobby, supra note 37 at II-137 suggests that "[i]n view of the transparency of the environmental assessment process and decision-making required by the Act, there would have to be demonstrable and likely compelling public benefits for permitting a project to be carried out notwithstanding significant adverse environmental effects.”

$43 \quad$ Alberta Wilderness Assn. v. Canada (Minister of Fisheries and Oceans) (1998), [1999] 1 F.C. 483 at para. 17 (C.A.).

$44 \quad$ Imperial Oil Resources Ventures Ltd. v. Canada (Minister of Fisheries and Oceans), 2008 FC 598, 36 C.E.L.R. (3d) 153 at para. 6.

45 This was the path followed by the applicants in Pembina. See Pembina, supra note 2 (Applicants' memorandum of argument in reply at para. 50) (August 2007) in the matter of Pembina, supra note 2 at para. 50 [on file with the author]: “[o]n its face, the Panel's dismissal of the greenhouse gas emissions of 800,000 cars as "insignificant” demands some explanation of the Panel's rationale.” 
The evidence in the Panel's report showed that Alberta's intensity targets placed limits on the amount of GHG emissions per barrel of oil produced and that the Kearl project would be subject to these targets. ${ }^{46}$ It was also clear, however, that the absolute amount of GHG emissions from the project would continue to rise because of a planned increase in total production. ${ }^{47}$ How, asked the Court, can intensity-based targets that do not constrain the absolute amount of GHG emissions constitute effective mitigation measures that reduce the project's GHG emissions to a level of insignificance? ${ }^{48}$ The Court found that without providing this vital link, the Panel breached its obligation to provide reasons for its EA decision. The Court summarized its holding as follows:

[G]iven the amount of greenhouse gases that will be emitted to the atmosphere and given the evidence presented that the intensity based targets will not address the problem of greenhouse gas emissions, it was incumbent upon the Panel to provide a justification for its recommendation [that GHG emissions would be insignificant]. By its silence, the Panel short circuits the two step decision making process envisioned by the CEAA which calls for an informed decision by a responsible authority. ${ }^{49}$

Thus, significance was at the core of the Court's difficulty with the Panel's conclusion. It is necessary, therefore, to bring some attention to the meaning of the word significant as it is understood in EA practice.

\section{SIGNIFICANCE}

\section{A. DEFINING SignificANCE}

As demonstrated in Pembina, discharging a panel's legal obligations under the CEAA requires a discussion of significance. The EA will always narrow down to a decision of whether the project is likely to cause significant adverse environmental effects. ${ }^{50}$ However, the precise meaning of significance is not readily ascertained. It has been commented that “[v]erbal descriptions of 'significance' are not very illuminating and mathematical ones are generally impossible." 51 The courts have resisted interfering with determinations of significance, stating that significance is not a wholly objective exercise, and it contains a large measure of opinion and judgment. ${ }^{52}$ In the Federal Court of Appeal's opinion, "[r]easonable people can and do disagree about the adequacy and completeness of evidence

Pembina, ibid. at para. 78.

Ibid. Emissions intensity is measured by dividing actual emissions by production, and intensity targets are set on the basis of allowable emissions per unit of production from a facility. For example, the emissions intensity target for the Kearl project is $40 \mathrm{~kg}$ of $\mathrm{CO}_{2} \mathrm{e}$ emissions per barrel of oil produced (Panel Report, supra note 1 at 58). Provided that production rises, it is possible to meet intensity targets while increasing actual emissions.

Pembina, ibid. at para. 78.

Ibid. at para. 79 [emphasis in original].

Federal Environmental Assessment Review Office, "Reference Guide: Determining Whether a Project is Likely to Cause Significant Adverse Environmental Effects” in Canada Environmental Assessment Agency, Responsible Authority’s Guide (Ottawa: Minister of Supply and Services Canada, 1994) 181 at 183 ["Significance Guide”].

Michael Herz, "Parallel Universes: NEPA Lessons for the New Property” (1993) 93 Colum. L. Rev. 1668 at 1714 [footnote omitted].

See Alberta Wilderness Assn. v. Express Pipelines Ltd. (1996), 137 D.L.R. (4th) 177 at 181 (F.C.A.) [Express Pipelines]. See also Pembina, supra note 2 at para. 22. 
which forecasts future results and about the significance of [environmental effects]." ${ }^{\text {} 33}$ For this reason, what is significant is not considered to be a matter of law. ${ }^{54}$ Rather, it is a technical determination driven by scientific evidence. A review panel, which is expected to have a high degree of expertise in environmental matters, must review all available evidence in order to make this determination. ${ }^{55}$

Determining what is significant under the CEAA first requires a consideration of environmental effects. "Environmental effect" is broadly defined by the $C E A A$ to include any change that the project may cause to the "environment," which itself is broadly defined to include all components of the earth, not limited to the environment in Canada. ${ }^{56}$ Environmental effects can also be indirect, for example, when an effect on the environment has an effect on socio-economic conditions. ${ }^{57}$ Once environmental effects are identified, it is necessary to identify whether those effects are adverse. One way to do this is to compare a baseline of environmental quality before the project with the predicted quality of the environment once the project is in place. ${ }^{58}$ This can be done by examining a number of variables, such as habitat loss, loss or damage to commercial resources, or the transformation of natural landscapes. Since examining the relationships between a number of variables can be very complex, a project's forecasted impacts can be compared to environmental standards or to alternative means of carrying out a project, as described below. Once adverse environmental effects have been identified, a panel must make a finding respecting the significance of each effect.

Determining significance is not a wholly objective exercise of applying fixed criteria to a particular environmental impact. ${ }^{59}$ While fixed criteria may in some cases provide useful indicators of environmental impacts, they can hide the assumptions or value judgments upon which the criteria are based. A transparent EA demands the disclosure of value judgments upon which the evaluative criteria are based. ${ }^{60}$ This is because the EA process is designed to accommodate a plurality of views, and no single value judgment is permitted to dominate the decision-making process. Primarily, articulations of significance must be expressed from an ecological standpoint. Because the CEAA mandates that only adverse environmental

Express Pipelines, ibid.

Ibid.

See Pembina, supra note 2 at para. 37 [footnotes omitted], where the Court commented on the applicable standard of review: "to the extent that the issues posed involve the interpretation of the the CEAA, as questions of law, they are reviewable on a standard of correctness ... [h]owever, issues relating to weighing the significance of the evidence and conclusions drawn from that evidence including the significance of an environmental effect are reviewed on the standard of reasonableness simpliciter." CEAA, supra note 3, s. 2(1).

Ibid. To be considered an environmental effect, a change in socio-economic conditions must be caused by changes in the environment. For example, a project that destroys fish habitat and results in job losses for local fishermen is a socio-economic effect caused by changes to the environment. However, a project that causes job losses as a result of the reallocation of funding is not a socio-economic effect attributable to a change in the environment.

"Significance Guide," supra note 50 at 187.

Jane Holder, Environmental Assessment: The Regulation of Decision Making (Oxford: Oxford University Press, 2004) at 145.

Wood, supra note 41 at 179 ("the basis upon which value judgments are made should be clearly explained since, while there may be agreement about the magnitude of impacts, different participants in the [EA] process are unlikely to agree about their significance"). 
effects be considered in determining significance, economic or social benefits caused by a project have no role to play in a significance determination and are not to be considered by panel reviews. By contrast, economic and social benefits might be used by a decision-maker to justify allowing a project to proceed despite its significant adverse environmental effects. ${ }^{61}$

Broadly, what will determine the significance of environmental effects will be the magnitude of the effect compared with the importance and sensitivity of the receptor. ${ }^{62} \mathrm{~A}$ minor effect, no matter how adverse, may not be considered significant, whereas a major effect will more likely be considered significant. Similarly, an effect on a highly sensitive environment, no matter what the magnitude, may be considered significant because of the value ascribed to the receptor. Understanding the context within which an environmental effect occurs is therefore vitally important.

Thus, determining significance requires an examination of both quantitative (magnitude) and qualitative (value) variables. However, a panel is not tasked with undertaking this examination in the abstract; all decisions about whether a project is likely to cause significant adverse environmental effects must be supported by findings of fact based on requirements in the CEAA. The panel has a duty to obtain all available information about environmental effects related to the project, to consider this information, to reach conclusions about the effects, and to substantiate those conclusions in its report. ${ }^{63}$

\section{B. ARticulating SignificAnCE IN THE GHG ConTEXT}

In 2003, the review panel for the Georgia Strait Crossing (GSX) pipeline project commented that because there are "no defined criteria to measure significance in relation to [GHGs],” the significance of a project's GHG emissions cannot be evaluated. ${ }^{64}$ To respond to this concern, it is necessary to briefly outline three important significance considerations: the magnitude of the GHG problem, the cumulative effect of GHG releases occurring across the globe, and the normative context in which climate change is occurring. Volumes of information on each of these considerations exist and are readily available to review panels faced with the prospect of determining the significance of environmental effects. ${ }^{65}$ Panels

61 Justification is made pursuant to the CEAA, supra note 3, s. 37(1)(a)(ii). See supra note 42 and accompanying text.

62 Wood, supra note 41 at 180.

63 Alberta Wilderness Assn. v. Cardinal River Coals Ltd., [1999] 3 F.C. 425 at 456 (T.D.) [Cardinal River Coals].

GSX Report, supra note 8 at 33.

One such source of information is the IPCC, which was established to "provide the world with a clear scientific view on the current state of climate change and its potential environmental and socio-econmic consequences.” Its role is to assess "the most recent scientific, technical and socio-economic information produced worldwide relevant to the understanding of climate change”: see "Organization,” online: IPCC <http://www.ipcc.ch/organization/organization.htm>. An international body like the IPCC provides a widely subscribed to and non-partisan view of the current state of climate change science. It is a uniquely placed body capable of assessing the effects of worldwide GHG emissions and its conclusions exist outside the realm of government policy. It produces precisely the kind of information that would be useful to review panels established under the CEAA. Other governmental and non-governmental sources of climate change science are readily available: see e.g. Pew Center on Global Climate Change, The Causes of Global Climate Change (August 2008), online: Pew Center on Global Climate Change <http://www.pewclimate.org/docUploads/global-warming-science-brief-august08.pdf> (non- 
must also exercise a high standard of care when considering environmental effects and must only substitute their own judgment where evidence on environmental effects is either unavailable or inaccessible. ${ }^{66}$ Because the information is readily available, predictive uncertainty, said to be an indelible weakness in EA and the subject of much criticism, ${ }^{67}$ might actually be reduced in the climate change context.

\section{MAGNITUDE}

There are several ways to characterize the magnitude of an environmental effect, no single one of which is determinative. Some of the most common indicators include the geographic extent of the effect, its duration, the degree to which an effect is irreversible, and the ecological context within which an environmental effect is felt. ${ }^{68} \mathrm{GHG}$ emissions, as a whole, impact every one of these indicators. Central to the examination of the magnitude of GHG impacts is the realization that current global levels of GHGs are already causing climate change effects. ${ }^{69}$

The geographic extent of climate change effects is unlimited. Climate change is, by its nature, a global problem, and exhibits the hallmark characteristics of a "tragedy of the commons."70 In contrast to point-source pollution, which may lead to a build up of undesirable environmental effects in a discernible geographic area, it matters little where GHGs are emitted. ${ }^{71}$ Once released, locally emitted GHGs become indistinguishably mixed in the global atmosphere with GHGs emitted from sources around the world. As a result, a tonne of $\mathrm{CO}_{2}$ e emitted in India will have the same harmful effect on Canada as a tonne of $\mathrm{CO}_{2} \mathrm{e}$ emitted locally. ${ }^{72}$ To be clear, while the degree of climate change impacts will be felt differently around the world, the degree of impacts felt in a particular place does not depend on the amount of GHG emissions released in that particular place. ${ }^{73}$

Some GHGs, including $\mathrm{CO}_{2}$, "are chemically stable and persist in the atmosphere over time scales of a decade to centuries or longer, so that their emission has a long-term influence

government); California Climate Change Research Center, Our Changing Climate: Assessing the Risks to California (July 2006), online: Union of Concerned Scientists <http://www.ucsusa.org/assets/ documents/global_warming/our-changing-climate-final.pdf > (government). Cardinal River Coals, supra note 63 at 449, 451-52.

Bradley C. Karkkainen, “Toward a Smarter NEPA: Monitoring and Managing Government's Environmental Performance” (2002) 102 Colum. L. Rev. 903 at 928.

“Significance Guide,” supra note 50 at 190.

IPCC Report, supra note 9 at 39.

Garrett Hardin, "The Tragedy of the Commons" (1968) 162 Science 1243; Richard B. Stewart, "Environmental Regulation and International Competitiveness” (1993) 102 Yale L.J. 2039 at 2055 (describing climate change as a classic example of the "tragedy of the commons").

Dave Owen, “Climate Change and Environmental Assessment Law” (2008) 33 Colum. J. Envtl. L. 57 at 66 .

Ibid. See also Elizabeth R. DeSombre, The Global Environment and World Politics, 2d ed. (London: Continuum International Publishing Group, 2007) at 113 ("emissions of harmful substances from anywhere in the world have an impact on the atmosphere that is not dependent on the location of emissions”).

IPCC Report, supra note 9 at 31 ("Observational evidence from all continents and most oceans shows that many natural systems are being affected by regional climate changes, particularly temperature increases”). 
on climate."74 Atmospheric GHG concentrations have been building up for a century and there is evidence to show that we are fast approaching an unsafe limit. It is estimated that, to reduce the risk of dangerous climate change, GHG concentrations in the atmosphere must be stabilized to 450 parts per million by $2050 .^{75}$ The long life of GHGs in the atmosphere is directly related to the irreversibility of their effects. What is certain is that, at current levels of emission, climate change is likely to lead to at least some irreversible impacts. ${ }^{76}$ What is uncertain is the magnitude of the irreversible impacts themselves, which will depend on the rate and magnitude of climate change. ${ }^{77}$

Finally, because of their global reach, the environmental effects of GHG emissions are certain to be felt in areas that have already been adversely affected by human activities and in areas that are ecologically fragile and have little resilience to imposed stresses. ${ }^{78}$ Of particular concern in this respect will be the impact of climate change on water resources, already scarce in many areas. ${ }^{79}$ Regardless of whether the environmental effects of GHG emissions on water resources will be benign or even beneficial in some areas, there is very high confidence that the negative impacts of climate change on freshwater systems overall outweigh the positive benefits. ${ }^{80}$

\section{GHGs: Individually Minor But CuMUlatively ConsideraBle}

If even large projects like Kearl are tiny in the context of global GHG emissions, is it possible to determine the significance of any one project's adverse environmental effects? The difficulty in ascertaining the magnitude of one single project's environmental effects on a global problem might be insurmountable were it not for the requirement for a panel to consider "any cumulative environmental effects that are likely to result from the project in combination with other projects or activities that have been or will be carried out." ${ }^{\text {"1 }}$ The basic purpose of a cumulative impacts assessment is to examine a project's aggregate, as opposed to individual, effects. ${ }^{82}$ It is precisely because GHGs combine incrementally from

Susan Solomon et al., eds., Climate Change 2007: The Physical Science Basis (Cambridge: Cambridge University Press, 2007) at 23-24. This has been recognized by the United States Supreme Court in Massachusetts v. Environmental Protection Agency, 549 U.S. 497 at 524-25 (2007) (discussing the incremental contribution of American automobile emissions on global GHG emissions). IPCC Report, supra note 9 at 67. The current concentration is estimated at 380 parts per million. Ibid. at 54.

Ibid. at 53 ("Anthropogenic warming could lead to some impacts that are abrupt or irreversible, depending upon the rate and magnitude of the climate change").

The "Significance Guide," supra note 50 at 190, indicates that the adverse environmental effects of projects may be significant if they occur in areas or regions that exhibit these characteristics.

This effect is the subject of a new study released by the IPCC on water: see Bryson Bates et al., eds., Climate Change and Water: Technical Paper of the Intergovernmental Panel on Climate Change (Geneva: IPCC Secretariat, 2008).

IPCC Report, supra note 9 at 49.

CEAA, supra note 3, s. 16(1)(a). Cumulative effects analysis is by no means novel, and, as a result, is perhaps less foreign than might be thought. For example, the concept of cumulative effects is the cornerstone of our democratic system of governance: except in the most extreme circumstances, no single vote will change the result of an election. Cumulative actions by thousands of voters determine who is elected to public office: see Owen, supra note 71 at 90, n. 178.

Holder, supra note 59 at 130. 
a variety of sources, and no one source in isolation seems important, that the concept of cumulative impacts is central to the significance of a project's GHG emissions. ${ }^{83}$

The proper inquiry in a cumulative effects assessment is not whether, relative to other GHG emissions, a project's GHG emissions appear to have a considerable impact. ${ }^{84}$ The proper question to ask is, combined with global GHG emissions, what is the magnitude of a project's impact? The answer to this must be that, when seen together, all GHG emissions worldwide create major environmental effects. Merely because a project's GHG emissions may be incrementally small does not make its cumulative impact any less real. ${ }^{85}$ This has been recognized by the Federal Court of Appeal, which noted, in obiter, that "[i]t is not illogical to think that the accumulation of a series of insignificant effects might at some point result in significant effects." 86

The concept of cumulative impacts requires that the greater the existing environmental problems are, the lower the threshold should be for treating a project's contribution to cumulative impacts as significant. ${ }^{87}$ The logic behind this is simple. If there is an upper limit to the amount of GHGs that the atmosphere can accommodate without risking dangerous climate change, ${ }^{88}$ then every individual release, building upon past releases, brings that limit closer. As the gap between the total emissions and the upper limit narrows, the greater the potential that limit will be exceeded. Where there is a greater potential that the limit will be exceeded, the more important every incremental contribution becomes. This does not necessarily mean, however, that every small GHG release must be labelled significant. As will be seen below, it is possible to articulate de minimis significance thresholds.

Thus, a cumulative impacts analysis eliminates the need to establish a direct causal link between an individual project's emissions and the resulting climate change consequences. Because cumulative impacts allow GHG emissions to be examined as an aggregate, it is not necessary for the purposes of the CEAA to directly link, for example, a particular environmental effect to specific GHG emissions from one oil sands installation. It is (9th Cir. 2007) ("The impact of greenhouse gas emissions on climate change is precisely the kind of cumulative impacts analysis that [is required]"). While cumulative impacts have received little attention in Canada, considerable jurisprudence has arisen in the U.S. with respect to cumulative impacts analysis. Seeking guidance on this issue from American courts can therefore be instructive, and is certainly not without precedent. The U.S. experience under the National Environmental Policy Act of 1969, 42 U.S.C. $\S 4321$ (1970) [NEPA] has proven to be instructive to the highest Canadian court: see Oldman River, supra note 20 at 40 (where LaForest J. looked to NEPA for guidance on the general principles of environmental assessment legislation).

Imperial Oil pointed to the relative amount of emissions from the Kearl project in Pembina, supra note 2 at para. 70.

See generally Communities for a Better Environment v. California Resources Agency, 103 Cal.App.4th 98 at 114 (2002) [Communities for a Better Environment] ("One of the most important environmental lessons that has been learned is that environmental damage often occurs incrementally from a variety of small sources. These sources appear insignificant when considered individually, but assume threatening dimensions when considered collectively with other sources with which they interact"). Friends of the West Country Assn. v. Canada (Minister of Fisheries and Oceans) (1999), [2000] 2 F.C. 263 at 288 (C.A.), Rothstein J.A. [Friends of the West].

Communities for a Better Environment, supra note 85 at 119-20.

IPCC Report, supra note 9 at 65. 
sufficient that cumulative impacts from other GHG emissions have been found to cause such an effect.

\section{CONTEXT}

Value judgments that inform the significance of a project's environmental effects depend on the factual context within which EAs are performed. If significance is contextual, where can the context be found? It is found, partly, in the increasing public awareness around oil sands development and GHG emissions. ${ }^{89}$ It is found, partly, in Canada's international obligations. ${ }^{90}$ It is found, certainly, in the broad scientific agreement on the effects of GHG emissions on climate change. While these factors combine to exert a normative influence on the context within which a significance determination is made, one need look no further than Pembina to find that there is likely to be disagreement on the weight ascribed to certain value judgments in any particular context. It is precisely because of that disagreement that a plurality of views must be considered. The combination of these views provides the context for the significance determination. Only after the context has been considered, and competing values have been evaluated, can a final significance judgment be made.

When seen this way, the Panel's reasoning in Pembina becomes even more indefensible. Alberta's intensity targets, animated by the Alberta government's value judgments, were permitted to dominate the significance discussion. Making reference to its commitment to the continued production and use of fossil fuels, Alberta has stated that it is "not prepared to forgo the opportunities our strong and vibrant economy provides" in favour of restrictive climate change policies. ${ }^{91}$ While this rationale may be satisfactory as a political justification at the decision-making stage of EA, it is beyond the scope of what is to be considered under the CEAA, and as such cannot be accommodated in EA preparation. Thus, the Panel's error was twofold: it used intensity targets motivated by economic justifications as a proxy for significance, and by doing so it categorically excluded a consideration of the factual context within which a significance determination must be made. Given what is known about the magnitude of climate change impacts and the consequence of those impacts on the global environment, it is apparent that the normative context within which the Kearl project's emissions must be placed is far more complex than admitted by Alberta's intensity targets.

Ultimately, it was perhaps open to the Panel to conclude that the project's impacts were insignificant. Similarly, it might be open to future panels to come to the same conclusion on other oil sands projects. But where intensity targets are used as a proxy for aggregate community values, and where the premise for those values is not disclosed nor considered

Climate change litigation like that seen in Pembina and Friends of the Earth $v$. Canada (Governor in Council), 2008 FC 1183, 336 F.T.R. 117, are testament to the public's increasing sensitivity to climate change issues.

90 See generally Meinhard Doelle, The Federal Environmental Assessment Process: A Guide and Critique (Markham: LexisNexis, 2008) at 48 (explaining the influence of international commitments on the interpretation of CEAA). Canada's international obligations are found in the United Nations Framework Convention on Climate Change, 9 May 1992, 1771 U.N.T.S. 107 (entered into force 21 March 1994) [UNFCCC] and the Kyoto Protocol to the United Nations Framework Convention on Climate Change, 11 December 1997, 2303 U.N.T.S. 148 (entered into force 16 February 2005) [Kyoto Protocol].

91 Alberta's 2008 Climate Change Strategy: Responsibility/Leadership/Action (January 2008) at 13, online: Alberta Environment <http://environment.gov.ab.ca/info/library/7894.pdf>. 
in relation to the prevailing context, it is likely that a court will find that significance has not been addressed in accordance with the CEAA requirements. In the interests of objectifying the context in which significance judgments are made, and to respond to the concern that there are no defined criteria to measure significance in relation to GHGs, it would be useful to articulate a threshold of significance, or "an identifiable quantitative, qualitative or performance level that marks the division between an impact that is significant and one that is not."92

\section{STANDARDS OF SIGNIFICANCE}

\section{A. THE REGULATORY APPROACH: IDENTIFIABLE THRESHOLDS}

The relationship between thresholds and EA procedure is complex and merits some consideration. If a project's fate is tied to a determination of whether or not its GHG emissions have a significant environmental impact, and if significance is indexed to an emissions threshold, one might presume that projected emissions could easily be compared with the relevant threshold without the necessity of carrying out a full EA. Would such a predetermination not render the EA process meaningless? The answer to this is composed of two parts. First, a project's adherence to emissions thresholds is only one part of the EA. Other environmental effects, such as water quality or the capacity of renewable resources to be affected by the project must still be examined. Second, few projects with considerable GHG emissions are likely to satisfy a stringent emissions threshold without the adoption of mitigation strategies, the effectiveness of which would need to be examined in an EA.

Whether or not a benchmark can fulfill the role of determining what is or is not significant depends on an examination of the benchmark itself. Significance is an ecologically driven consideration. This creates problems for some standards, such as intensity targets, which are politically set. Political standards may, for example, ignore the importance of cumulative impacts. It is important that any standard used in the significance determination not be permitted to pre-empt the values the $C E A A$ is intended to protect, not the least of which are environmental protection and public participation. ${ }^{93}$

After Pembina, it is clear that it is no longer sufficient for review panels to relieve themselves of their responsibility to objectively examine a project's significant environmental impacts solely by referencing government policy that is, on its face, inconsistent with the GHG stabilization goals identified by the scientific community. Bearing in mind the cumulative effects discussion above, it is likely that the normative influence from the scientific community will continue to bear on the perception of what is considered significant. In this context, it is possible that the threshold required to reasonably reduce a project's GHG emissions down to a level of insignificance might approach full neutralization of GHG emissions. 
A “zero-threshold," however, is potentially paralyzing and therefore not workable. Furthermore, it is probably not necessary in light of two realizations. ${ }^{94}$ First, given that the maximum carrying capacity for "unsafe” levels of GHG emissions has not yet been reached, some level of emissions from new and existing projects is probably still consistent with climate stabilization. Second, other policy initiatives are already working to reduce GHG emissions from a number of sources, decreasing the risk that the upper limit of unsafe levels of GHG emissions will be exceeded. ${ }^{95}$

One way to formulate a threshold for GHG emissions would be to identify, through regulation, a quantitative threshold below which a project's GHG emissions would be considered insignificant. This would serve to objectify significance and, as a result, promote consistency in EA. In formulating such a threshold, it must be recognized that some sectors emit considerably more GHGs than others, and as a result, should have a greater obligation to reduce emissions. Thus, sector specific thresholds would be appropriate. California has commenced an approach whereby it has used emissions data to situate individual project emissions within representative emissions from that sector. ${ }^{96}$ This data was used to create a technical foundation to differentiate between smaller, less significant projects, and larger, more significant projects. Public input has been sought to comment on the proposed thresholds, with the presumed outcome that the public will have vetted any final thresholds before they are expressed as a regulatory mandate. Such an approach, which combines technically driven criteria with public perceptions of what is considered significant, is consistent with the theoretical basis for significance as it is understood in EA. Moreover, such an approach is compatible with the CEAA, which permits the creation of general regulations "for carrying out the purposes and provisions" of the CEAA. ${ }^{97}$

\section{B. The Judicial Approach: ANAlysis of Alternatives}

In the absence of an absolute significance threshold expressed through regulation, alternatives can be used to identify a project's relative significance. Alternatives provide a comparison from which decision-makers can determine whether a proposed project has the least significant environmental effects, or, in the GHG context, whether a proposed project emits the least possible GHG emissions amongst similar projects that achieve the same goal. The CEAA requires an analysis of "alternative means of carrying out the project that are technically and economically feasible and the environmental effects of any such alternative means." 98 This mandatory consideration provides potential litigants with an opportunity to ensure that alternatives are properly scrutinized through judicial review.

Alternatives can exist on a project or on a sub-project scale. On a project scale, an alternatives inquiry consists of finding alternatives to the entire project. However,

$94 \quad$ California Air Resources Board, supra note 92 at 4.

95 For a federal policy initiative, see e.g. Turning the Corner, supra note 13; for a regional initiative, see e.g. online: Western Climate Initiative <http://www.westernclimateinitiative.org $>$.

96 California Air Resources Board, supra note 92 at 4-5. The California Environmental Quality Act, 13 Cal. Pub. Res. Code $\S \S 21000-21177$, like many EA statutes around the world, uses significance to gauge a project's adverse environmental effects.

$97 \quad$ CEAA, supra note 3, s. 59(n).

$98 \quad$ Ibid., s. 16(2)(b). 
alternatives inconsistent with the scope of the project need not be considered. ${ }^{99}$ Where, for example, project goals are straightforward, such as the production of 400 megawatts of energy, a project level alternatives inquiry might yield some real alternative options, such as the favouring of a gas-fired power plant over a coal-fired one. ${ }^{100}$ Yet, an alternatives analysis must also be pragmatic. Currently, it may be unrealistic to think that there are alternatives to oil sands exploitation at the project level that are acceptable from an economic or geopolitical standpoint, let alone the project proponent's standpoint. In the Kearl project, for example, project level alternatives were never discussed. ${ }^{101}$ This is for two reasons: Imperial Oil's stated purpose of the project was inseparable from the means to carry it out, and the Minister scoped the consideration of project alternatives according to the stated purpose. ${ }^{102}$

What is more likely is that sub-project alternatives, such as alternative industrial process options, will present viable GHG reduction options for project proponents. These could include using different infrastructure to accomplish project purposes or mandating that a project's energy requirements come from renewable sources. It is incumbent on a review panel to not only identify alternative means of carrying out the project, but also to discuss comparative environmental effects. ${ }^{103}$ With respect to GHGs, this was not done in the Kearl project. Apart from stating that "Imperial Oil's approach for the Kearl project is to select the most energy efficient, commercially proven, and economic technology as a means to minimize GHG emissions," there is no indication that Imperial Oil evaluated the comparative GHG emissions from alternative processes used. ${ }^{104}$ Without a comparative analysis of GHG emissions from sub-project alternatives, one is left to rely on Imperial Oil's judgment that the most emissions efficient processes were in fact chosen.

If alternatives are to be used to encourage proponents to minimize GHG impacts from the project as a whole, it will be necessary for courts to demand that proponents perform an analysis of the comparative GHG impacts of alternative technologies. Without strict enforcement, alternatives are incapable of yielding a relative standard at all. Furthermore, to achieve GHG reductions such an analysis must also yield substantive outcomes. This is

Express Pipelines, supra note 52 at paras. 181-82. The RA, or when applicable, the Minister of Environment, has considerable discretion in scoping the extent of alternatives to be considered: see CEAA, ibid., s. 16(3).

In this case, the alternative with the least overall emissions would be preferable from the perspective of reducing significant adverse environmental effects.

Only sub-project alternatives, such as tailing pond locations and mine pit limits with regard to river diversions were discussed in the Kearl EA: see Panel Report, supra note 1 at 15-16. See also Imperial Oil Resources Ventures Limited, Kearl Oil Sands Project - Mine Development (July 2005) vol. 1 at 11-3, online: Canadian Environmental Assessment Agency <http://www.ceaa.gc.ca/050/DocHTML Container_e.cfm? DocumentID=18778> [Imperial Assessment] (Regulatory application submitted to the Alberta Energy and Utilities Board).

Panel Report, ibid. at 15 ("Imperial Oil stated that the purpose of the [Kearl] Project was to develop oil sands mining and processing facilities to produce clean bitumen from its Crown oil sands leases”). Cardinal River Coals, supra note 63 at 463. But see Sharp v. Canada (Transportation Agency) [1999] 4 F.C. 363 at 463 (C.A.), leave to appeal to S.C.C. refused, (1999), 252 N.R. 391 at para. 26 [Sharp], where the Court stated that business or commercial needs are a legitimate basis for rejecting alternatives. However, since Sharp involved a challenge to a comprehensive review (i.e., an EA with a lower level of public scrutiny than a panel review), it is unclear to what extent a court would be willing to reject viable options on the basis of business or commercial needs. 
currently not the case. While a panel must analyze alternatives, the jurisprudence dictates that it is under no obligation to choose the alternative with the least environmental impact. ${ }^{105}$ Without a judicial doctrine to mandate the adoption of the best alternatives, an alternatives analysis contributes little to the achievement of the CEAA's goals.

Given the magnitude of cumulative GHG impacts, it may now be incumbent on courts to ensure that a full range of project and sub-project level alternatives are critically examined by review panels. The Supreme Court of Canada has emphasized that legal measures to protect the environment "relate to a public purpose of superordinate importance" and that "environmental protection [has] emerged as a fundamental value in Canadian society."106 These clear statements, combined with a re-articulation of the standard of review in Dunsmuir,${ }^{107}$ arguably demand a more exacting form of judicial review aimed at ensuring a review panel discharges its obligations in good faith and provides convincing reasons for its conclusions. ${ }^{108}$ This is consistent with the requirement in Dunsmuir that, under the reasonableness standard, agencies produce a decision that "falls within a range of possible, acceptable outcomes which are defensible in respect of the facts and law."109

The advantage of an alternatives analysis over the adoption of clear significance thresholds is that while it requires stringent judicial oversight, it does not depend on regulatory will. The disadvantage is that it lacks clarity. A proxy standard for significance, such as the one an alternatives analysis provides, may achieve emission reductions on an individual project basis, but it lacks the consideration for overall context that an identifiable significance threshold provides. Mandating that the most emissions efficient alternatives be adopted might be useful as an interim measure before identifiable significance thresholds can be articulated, but ultimately, merely because an alternative is less significant does not make it insignificant.

\section{Mitigation: ToWARD INSIGNIFICANCE}

\section{A. Degree OF Mitigation}

Few projects with considerable GHG emissions are likely to satisfy identifiable significance thresholds. Similarly, even where the best available alternatives are adopted, GHG emissions may still be considerable. This does not, however, mean that project approval must be paralyzed. The CEAA still affords two avenues by which projects can gain

Inverhuron \& District Ratepayers' Assn. v. Canada (Minister of the Environment), 2001 FCA 203, 273 N.R. 62 at para. 50, leave to appeal to S.C.C. refused, (2002), 289 N.R. 399.

R. v. Hydro-Québec, [1997] 3 S.C.R. 213 at paras. 85, 124; 114957 Canada Ltée (Spraytech, Société d'arrosage) v. Hudson (Town of), 2001 SCC 40, [2001] 2 S.C.R. 241 at para. 1. See also British Columbia v. Canadian Forest Products Ltd., 2004 SCC 38, [2004] 2 S.C.R. 74.

Dunsmuir v. New Brunswick, 2008 SCC 9, [2008] 1 S.C.R. 190 [Dunsmuir].

This concept, called the "hard look" doctrine, has been expounded by American courts to ensure that agencies conducting an EA pay more than mere lip service to environmental issues and treat the issues in a genuine fashion: see Neil Craik, The International Law of Environmental Impact Assessment: Process, Substance and Integration (Cambridge: Cambridge University Press, 2008) at 36; Cass R. Sunstein, "In Defense of the Hard Look: Judicial Activism and Administrative Law" (1984) 7 Harvard J.L. \& Pub. Pol'y 51 at 52.

Dunsmuir, supra note 107 at para. 47. 
approval. The first avenue is through a discretionary decision whereby the decision-maker must balance competing societal values in order to justify project approval. ${ }^{110}$ The second avenue, whereby mitigation measures can be relied upon to temper a finding of significance, is deserving of attention here. ${ }^{111}$

The term mitigation is given a broad definition in the CEAA: “'mitigation' means, in respect of a project, the elimination, reduction or control of the adverse environmental effects of the project, and includes restitution for any damage to the environment caused by such effects through replacement, restoration, compensation or any other means."112

Mitigation is open to varying interpretations. Under the above definition, there does not appear to be a minimum threshold for what degree of mitigation would be considered sufficient for the purposes of the CEAA. For example, would it be sufficient for a proponent to mitigate GHG emissions from 800,000 tonnes of $\mathrm{CO}_{2} \mathrm{e}$ down to 400,000 tonnes of $\mathrm{CO}_{2} \mathrm{e}$ ? Bearing in mind the cumulative effects discussion above, it would certainly be difficult to make an argument that, despite halving project emissions, 400,000 tonnes of GHG emissions per year is insignificant. Short of full restitution, which in this example can be understood as fully offsetting all 800,000 tonnes of project GHG emissions, the definition of mitigation does little to provide guidance on whether a project should be considered significant.

Clear guidance on what level of mitigation might be required to satisfy a level of insignificance can of course be found in a significance threshold. Mitigation guidelines could be developed in a process similar to the one proposed in California to identify significance thresholds. ${ }^{113}$ Again, together with stakeholders, sector specific guidelines could be developed so as not to paralyze certain industries. This would have the advantage of providing consistency in project approvals as well as increasing public confidence in the process. Where emissions are beyond a certain level, successful projects under the $C E A A$ would be required to neutralize GHG emissions back down to that acceptable threshold level.

In the absence of a clear de minimis threshold, another option would be to adopt an interpretation of mitigation that is closer to full restitution. This would require adopting a carbon neutral standard. Adopting a carbon neutral standard may seem severe, but carbon

110 CEAA, supra note 3, s. 37(1)(a)(ii) ("the project is likely to cause significant adverse environmental effects that can be justified in the circumstances”). See also Part II.C, “The Responsible Authority’s Decision," above.

111 CEAA, ibid., s. 37(1)(a)(I) [emphasis added] ("where, taking into account the implementation of any mitigation measures that the responsible authority considers appropriate, the project is not likely to cause significant adverse environmental effects." A word of clarification to the reader: in Express Pipelines, supra note 52 at 182, it was held that mitigation and environmental effects ought to be considered together. Nothing in this article should be taken to detract from that statement. Mitigation and significance are treated separately here for clarity only. Where it is known that a project's environmental effects can be mitigated, its environmental effects need not be considered. However, where it is less than clear that mitigation measures will be effective in reducing environmental impact, it will be necessary to conduct a more reaching analysis of proposed mitigation measures.

112 CEAA, ibid., s. 2.

113 California Air Resources Board, supra note 92. See also Part IV.A, “The Regulatory Approach: Identifiable Thresholds,” above. 
neutrality is gaining traction as both a legislative and policy initiative. ${ }^{114}$ Additionally, the requirement of full restitution as a mitigation measure is well-established in EA. The destruction of fish habitat, for example, is often mitigated by the completion of a "no net loss plan," which requires habitat compensation to a level at least equal to the amount of habitat forecasted to be destroyed by a project. ${ }^{115}$ The concept of no net loss guidelines used to satisfy the Fisheries Act could be applied to the climate change context to develop a "no net gain" standard, the fulfillment of which would be sufficient to satisfy mitigation measures on the issue of GHG emissions. ${ }^{116}$

However, for reasons identified above, a carbon neutral mitigation standard is certain to be controversial, and is probably not necessary. Carbon neutrality, however, has gained some traction in EA literature and may at some point become attractive if we are to meet the longterm absolute GHG emissions reductions targets found in the federal government's Turning the Corner plan. ${ }^{117}$ Therefore, if certain industries wish to avoid the adoption of such a stringent standard, they have an incentive to work with other stakeholders to identify a clear significance standard.

\section{B. EMissions Trading: Method OF Mitigation?}

Regardless of what degree of mitigation will be required, it is inescapable that emissions trading will be required if a large project's GHG emissions are to be offset to an insignificant level. This raises questions as to what kind of emissions trading might reasonably be relied upon to constitute adequate mitigation measures. A foreseeable demand for carbon offsets also raises questions about whether there will be a sufficient supply of offsets available to project proponents. The federal government's Turning the Corner program has embraced emissions trading as part of its goal to reduce Canada's total GHG emissions by 20 percent relative to 2006 by $2020 .{ }^{118}$ The plan offers three compliance measures: purchasing credits on the domestic carbon market, purchasing international credits, and contributing to a technology fund. A detailed analysis of these credits is beyond the scope of this article. ${ }^{119}$

For example, the British Columbia Greenhouse Gas Reductions Targets Act, S.B.C. 2007, c. 42, s. 5, which requires all public sector organizations, including government, to become carbon neutral by 2010. Pembina, supra note 2 at para. 47; The Department of Fisheries and Oceans Policy for the Management of Fish Habitat (Ottawa: Department of Fisheries and Oceans, 1986) at 12.

Fisheries Act, supra note 18. There are many theoretical similarities between fisheries and GHG emissions. To begin, they share an important characteristic in that they are both "common resource problems.” Furthermore, the "no net loss” policy is tied to the long-term DFO objective of an overall net gain in productive capacity of fish habitat. In the Kearl project, this translated into the construction of a "compensation lake" for the full restitution of fish habitat. A similar case could be made for emissions under the Federal government's Turning the Corner plan. Although the plan does not use the language "overall net reduction," this is implicit from the goal of achieving a net reduction in emissions from a 2006 baseline by 2020. This long-term goal could justify the adoption of a "no-net gain" strategy. Since the "no-net loss" principle is not dependent on regulation, an argument could be made that a "nonet gain” strategy need not be either.

Shi-Ling Hsu \& Robin Elliot, "Regulating Greenhouse Gases in Canada: Constitutional and Policy Dimensions” 54 McGill L.J. [forthcoming in 2009] at 63-64 (“a panel might be reasonably called upon to ensure that any project subject to the CEA Act be 'carbon neutral.”') The federal government intends to adopt fixed emissions caps in the 2020-2025 period: see Turning the Corner, supra note 13 at 21. Turning the Corner, ibid.

For an overview of Canada's proposed emissions trading scheme from a legal perspective, see Stewart A.G. Elgie, “Carbon Offset Trading: A Leaky Sieve or Smart Step?” (2007) 17 J. Envtl. L. \& Prac. 235. 
They are worth brief mention, however, not for the purpose of outlining their details, but to examine whether offsets satisfactory to Turning the Corner could also be relied upon as mitigation measures under the CEAA.

Regulated emitters subject to Turning the Corner will be permitted to contribute to a technology fund in order to offset their emissions. It is described as the "key compliance mechanism," and was designed to allow industry to meet a substantial part of its emissions reductions obligations. ${ }^{120}$ In the near term, the technology fund will focus on deploying existing technology and infrastructure, and in the long-term includes research and development. The fund operates as a tax on emitters who do not meet their regulatory obligations, but there is no requirement that the fund result in verifiable emissions reductions.

When evaluated through the $C E A A$ jurisprudence, it is unlikely that the technology fund would constitute a reasonable mitigation measure for the purposes of the Act. In the context of a panel assessment, "research and development do not constitute mitigation measures." ${ }^{21}$ While over time, the technology fund may yield technologies capable of reducing GHG emissions, mere contribution to a fund does not constitute a mitigation measure capable of reducing an individual project's GHG emissions. Furthermore, there is no guarantee that the technology fund will in fact yield emissions reductions technologies. In approving a project, RA's are not entitled to rely on proposed mitigation measures over which they have no control. ${ }^{122}$

Other offsets proposed under Turning the Corner may be more suitable as mitigation measures. Domestic offsets, for example, must actually result in a net reduction of GHGs. ${ }^{123}$ These reductions must be verified in order to provide a reasonable level of assurance that the offsets claimed for the project have in fact been realized. Similar requirements exist for credits under the Kyoto Protocol's clean development mechanism. ${ }^{124}$ Given the RA's obligation to ensure the implementation of mitigation measures, the verifiability of emissions reductions will be a likely requirement for emissions offsets under the $C E A A \cdot{ }^{125}$ Certainly, emissions trading has the potential to reduce project emissions to an insignificant level, but until the final details of the offset program are released, it cannot be said with certainty that compliance measures under Turning the Corner will pass legal muster under the CEAA. ${ }^{126}$

Turning the Corner, supra note 13 at 14.

Pembina, supra note 2 at para. 25.

Environmental Resource Centre v. Canada (Minister of the Environment), 2001 FCT 1423, 214 F.T.R. 94 (Ministerial mitigation decisions unreasonable because they relied on mitigation measures proposed and in place for Alberta over which they had no control).

See Environment Canada, Canada's Offset System for Greenhouse Gases: Guide for Protocol Developers, Draft for Consultation (Ottawa: Environment Canada, 2008) at 2-3, online: Environment Canada <http://www.ec.gc.ca/creditscompensatoires-offsets/7CAD67C6-B798-4B69-9648-BD7F1F7 4B2CB/June10_protocol_eng_COM618_Guide_for_Protocol_Developers_AUG7.pdf>.

United Nations Framework Convention on Climate Change, Report of the Conference of the Parties serving as the meeting of the Parties to the Kyoto Protocol on its first session, held at Montreal from 28 November to 10 December 2005, 2006, UN Doc. FCCC/KP/CMP/2005/8/Add.1 at para. 61. CEAA, supra note 3, s. 37(2.2) (RA shall ensure implementation of mitigation measures). It is expected that the final Guide for Protocol Developers will released in fall 2009. 


\section{CONCLUSION}

Pembina highlights that significance is central to the EA process. A review of climate change science, readily available to the public, reveals that the apparent difficulty presented by the term significant is not debilitating. When the cumulative effects of one project's GHG emissions are examined, it is possible to articulate the meaning of significance in the climate change context. Merely establishing the magnitude of cumulative GHG emissions is insufficient, however, to establish significance. The clearest articulation of significance could be achieved through the establishment of regulatory thresholds. Establishing thresholds permits the technical foundation of significance to be validated through a public review process with a concomitant consideration for normative context. In the absence of clear thresholds, potential litigants might be successful in reducing a proposed project's adverse environmental impacts by demanding a more robust evaluation of alternatives in the courts. This would serve, at least, to establish a relative significance threshold.

The goal of these efforts is not to force a finding of significance every time a project with considerable GHG emissions is proposed. It is to articulate an ecologically based definition of significance. Where GHG emissions are found to be significant, it is open to an RA to justify a project in the circumstances. Where justification is not forthcoming, mitigation measures can be used to minimize project emissions towards insignificance. Coupled with the $C E A A$ 's procedural requirements, incremental developments in the regulatory sphere or through judicial doctrine could result in future EA decisions that are more consistent with climate change science. 